\title{
No Right to Be Wrong: What Americans Think about Civil-Military Relations
}

\author{
Ronald R. Krebs, Robert Ralston and Aaron Rapport
}

\begin{abstract}
An influential model of democratic civil-military relations insists that civilian politicians and officials, accountable to the public, have "the right to be wrong" about the use of force: they, not senior military officers, decide when force will be used and set military strategy. While polls have routinely asked about Americans' trust in the military, they have rarely probed deeply into Americans' views of civil-military relations. We report and analyze the results of a June 2019 survey that yields two important, and troubling, findings. First, Americans do not accept the basic premises of democratic civil-military relations. They are extraordinarily deferential to the military's judgment regarding when to use military force, and they are comfortable with high-ranking officers intervening in public debates over policy. Second, in this polarized age, Americans' views of civil-military relations are not immune to partisanship. Consequently, with their man in the Oval Office in June 2019, Republicans—who, as political conservatives, might be expected to be more deferential to the military - were actually less so. And Democrats, similarly putting ideology aside, wanted the military to act as a check on a president they abhorred. The stakes are high: democracy is weakened when civilians relinquish their "right to be wrong."
\end{abstract}

A list of permanent links to Supplemental Materials provided by the authors precedes the References section.

* Data replication sets are available in Harvard Dataverse at: https://doi.org/10.7910/DVN/MAIUD8

Ronald R. Krebs (1) is Beverly and Richard Fink Professor in the Liberal Arts and Professor of Political Science at the University of Minnesota (rkrebs@umn.edu). His most recent book is Narrative and the Making of U.S. National Security (Cambridge University Press, 2015), and he is coeditor, with Thierry Balzacq, of the forthcoming Oxford Handbook of Grand Strategy. He is editor-in-chief of the journal Security Studies.

Robert Ralston (1) is a Grand Strategy, Security, and Statecraft Fellow jointly appointed at the International Security Program, Belfer Center for Science and International Affairs, Harvard Kennedy School, and the Security Studies Program, MIT (robert_ralston@hks.harvard.edu). He received his Ph.D. from the University of Minnesota in 2020.

Aaron Rapport was, until his untimely passing in June 2019, lecturer in the Department of Politics and International Studies and a fellow of Corpus Christi College at the University of Cambridge (UK). He was the author of Waging War, Planning Peace:

U.S. Noncombat Operations and Major Wars (Cornell University Press, 2015).
S ince winter 2017, when Donald Trump entered the White House, there has been much discussion of the condition of democratic civil-military relations in the United States. Trump's early adulation of "my generals," and his decision to delegate many decisions about the use of force to the military, prompted concern. ${ }^{1}$ At the same time, when tensions heated up with North Korea in spring 2017, and many feared that Trump's impetuous decision-making might lead to nuclear war, informed observers questioned whether the uniformed military would or should obey the president's direct order to launch a nuclear weapon. ${ }^{2}$ As president, Trump repeatedly dragged the armed forces into partisan politics by addressing U.S. forces as if at a rally, and some troops responded by wearing MAGA (Make America Great Again) hats during his visits to U.S. military bases. ${ }^{3}$ In November 2019, he jumped past the guardrails of military autonomy, overruling its decisions about personnel and justice by issuing pardons to service members convicted of or charged with war crimes and insisting that a disgraced Navy SEAL be restored to his rank and station. Amidst the protests that exploded nationwide in June 2020 over police violence toward African Americans, Trump threatened to deploy active-duty U.S. military forces on the nation's streets. In response, many of the country's most respected, recently retired military officers broke their silence in criticism of the president. ${ }^{4}$ Finally, in the aftermath of his failed 2020 reelection campaign, Trump reportedly even entertained former adviser General 
Michael Flynn's proposal to send the military into swing states to "rerun" the election.

Trump's norm-breaching behavior has revived debate over classic questions about the proper policymaking roles of civilian officials and military officers. Democratic regimes in particular confront the question of "who guards the guardians": how to ensure that the armed forces are both capable - of protecting the nation against adversaries — and subservient - to the nation's political leaders. ${ }^{5}$ The democratic theory of civil-military relations, in Feaver's memorable phrase, thus insists that "civilians have the right to be wrong," because they are much more directly accountable to the people (Feaver 2003, 65). Put differently, this normative stance, which is widely accepted among both senior military officers and many civilian experts, asserts that while officers have a right and responsibility to advise civilian politicians and officials, they have no right to substitute their judgment for that of civilians. The will of civilians must reign supreme.

However, we find-in a survey, conducted in June 2019 and that is among the deepest examinations to date of what Americans think about civil-military relationsthat Americans do not subscribe to consensus tenets of democratic civil-military relations. Americans call for extraordinary deference to the armed forces, even on fundamental questions regarding when to use military force: if senior officers support a mission, nearly a majority of Americans would have the president approve it, even if he thinks the mission unwise, and a majority would grant the military a veto on the use of force. Whereas the traditional view enjoins officers to express their policy opinions only behind closed doors, Americans are not much bothered by the prospect of military officers, whether active-duty or retired, publicly intruding on policy debates.

One might have thought that, given the confidence huge majorities of Americans express in the armed forces, civil-military relations would be above politics. Perhaps the military would be an exception to our polarized age in which political tribalism regularly dominates ideological principle. Yet we find that political partisanship deeply informs how Americans approach the respective roles of civilian officials and military officers. Although liberals trusted the military less, they were in 2019 also more deferential to the military than were conservatives, and they even wanted the military to be more publicly vocal on policy. These views derived from partisan respondents' trust in Donald Trump. Republicans expressed great confidence in the armed forces, but those who trusted Trump wanted his preferences to become national policy, and they opposed a politically active military. Democrats, who distrusted Trump, wanted the military to act as a check on a president they abhorred. In a multivariate analysis, respondents' party identification and approval of Trump were strongly predictive of their deference toward the military, swamping the impact of political ideology. The impact of partisanship comes across clearly when comparing our results to a 2013 survey, when Barack Obama was president and partisan and ideological interests were aligned: Democrats then backed civilian supremacy, and Republicans called for deference.

It is generally unreasonable to expect the public's views to be in lockstep with scholars' normative theories. ${ }^{6}$ But the core claim of democratic civil-military relations - that the will of elected, accountable civilian officials should prevail-follows directly from the folk definition of democracy, to which Abraham Lincoln gave voice at Gettysburg in 1863, as government "of the people, by the people, for the people." Every American schoolchild can recite this folk definition of democracy, and therefore a U.S. public committed to democratic governance should oppose senior military officers driving the policy agenda or undermining the executive branch's capacity to set policy, let alone having a veto on the use of force. Yet we find that many Americans, sometimes a majority, have no problem with senior military officers making critical policy decisions and injecting themselves into policy debatecontrary to Lincoln's famous maxim.

We fill a significant gap in the field of civil-military relations. While across the world pollsters routinely ask about trust or confidence in various institutions, including the armed forces, they almost never ask more precise questions probing into the appropriate roles and limits of military officers in politics and decision-making. Perhaps, though, we need not worry much about public opinion. Perhaps scholars of civil-military relations have, for good reason, focused their analytical energies on institutions that cultivate military professionalism, socialize officers to obedience, or bolster civilians' capacity to monitor officers and hold them accountable (Feaver 1999, 2003; Huntington 1957; Janowitz 1960). Yet, we argue later, existing theories' tacit premise is that, if the military is to remain within its designated bounds, the public must grasp and endorse these norms. Our article's findings therefore raise troubling questions about the sustainability of democratic civil-military relations.

We proceed in six sections. First, we highlight the zone of normative consensus on democratic civil-military relations and explore the limits of existing scholarly knowledge of public opinion on these issues. Second, we describe the survey and its design. The next two sections unpack our two major findings. Fifth, we evaluate possible alternative explanations. We conclude by elucidating the implications for future scholarship and by addressing the findings' linked analytical and normative challenges.

\section{Civil-Military Relations and Public Opinion}

Over six decades ago, Huntington set out an influential account of what he believed to be the defining normative 
challenge of civil-military relations: how to create a military powerful enough to defend the nation but still subservient to civilians. He argued that encouraging military professionalism was the surest means of keeping the armed forces focused on its expertise-the application of force-rather than competing with civilians for supremacy. Professional officers, he believed, would then have little desire to throw themselves into the political arena. In exchange, according to this "normal theory" of civil-military relations (Cohen 2001, 2002), drilled into generations of U.S. military officers, civilian politicians were to keep out of the officers' domain of expertise (Huntington 1957). ${ }^{7}$ While the argument for "objective control" was contested from the start, ${ }^{8}$ the principle of civilian supremacy, which derived directly from the normative heart of democratic theory, was not. In the Huntingtonian vision, decisions regarding the use of military force would ideally arise from an iterative process of advisory collaboration between military officers and senior elected civilian politicians and appointed executive branch officials. Huntington feared that civilian, non-expert interference in military tactics and operations would harm national security, but he did not doubt their right to issue such orders, and he presumed that officers were duty-bound to obey those orders. Military officers, Finer powerfully argued, had "the right and the duty" to try "to persuade the government to their point of view" (Finer 1962, 137), ${ }^{9}$ but that right had to be circumscribed, to private settings - or else civilian control over policy would swiftly be rendered meaningless (Kemp and Hudlin 1992, 20-21).

Huntington's many critics generally called for a more active and intrusive civilian role. Observing that many professional officers in modern, technologically sophisticated armed forces are more expert in fields such as logistics and cryptography than in the application of force, military sociologists questioned whether greater civilian involvement would have the detrimental impact Huntington feared..$^{10}$ Cohen argued that, in fact, the intrusion of civilian leaders into military operations had historically often been for the good (Cohen 2002). Rooted in principal-agent theory, Feaver maintained that civilian control of the military had long depended not on giving officers autonomy, as Huntington advised, but the opposite. Only by carefully supervising the armed forces and punishing insubordination would civilians prevent the military from departing from their will (Feaver 2003).

Theorists of democratic civil-military relations thus generally embrace a large zone of normative consensus (in the core text of the following bullet points) and a smaller zone of normative dispute (in parentheses). The consensus' key propositions include:

- The judgment of civilian politicians should trump that of senior military officers regarding whether to undertake military missions. (But some argue that civilian politicians should defer to senior military officers over how to conduct military missions.)

- Military officers should express their views on military operations behind closed doors, not in public. (But some argue that they should publicly challenge patently illegal and immoral orders and that retired military officers should feel free to express their views in public.) $)^{11}$

- The armed forces should be subject to substantial civilian oversight. (But some argue that civilian oversight should be less intense on matters closest to the military's areas of professional expertise or its organizational prerogatives.)

The consensus is, moreover, reflected in the details of regional and intergovernmental organizations' policies and nongovernmental organizations' efforts seeking to promote "security sector reform" and "democratic control of the armed forces" around the world. ${ }^{12}$ Some noted theorists, most famously Janowitz, asked whether the armed forces might sustain democracy by nurturing civic virtue and fostering enthusiasm for public service (Janowitz 1960, 1983). But while such theorists therefore took issue with the strict normative stance that the military be "apolitical,"13 they did not take issue with the listed propositions. Burk's insightful, sympathetic reading of Janowitz revealingly begins by implicitly endorsing the normative consensus (Burk 2002, 8). ${ }^{14}$ Ongoing debates about military officers' principled resignations over policy differences-rather than illegal or immoral orders-reflect the normative consensus, with many analysts warning that the threat to resign can easily be used to subvert civilians' will and undermine civilian control (Brooks 2009, 220221; Feaver 2011, 94; Kohn 2002, 10). ${ }^{15}$

The literature generally theorizes democratic civilmilitary relations as emerging from the preferences and power of elites, civilian and military. However, these theories all acknowledge or imply that the views of the mass public are critical. Huntington's seminal book concludes that his recommendations are unsustainable unless the American body politic accepts that the military way of life is, and must be, distinct. America's liberalism has been "the real problem" to "the maximizing of civilian control and military professionalism." "Today America can learn more from West Point," Huntington (in)famously declares, "than West Point from America" (Huntington $1957,457,464,466)$. Although the text focuses largely on institutional arrangements, its final chapter revealingly puts mass culture and opinion at its analytical center. Feaver's principal-agent theory of civil-military relations also rests on a tacit foundation of supportive public opinion. One major impediment to civilian punishment of the military, he notes, is the military's "prestige that confers political power quite apart from any consideration of physical coercion" and its capacity to mobilize supporters in Congress and civil society (Feaver 2003, 88- 


\section{Figure 1}

\section{U.S. public confidence in the U.S. military, 1967-2018}

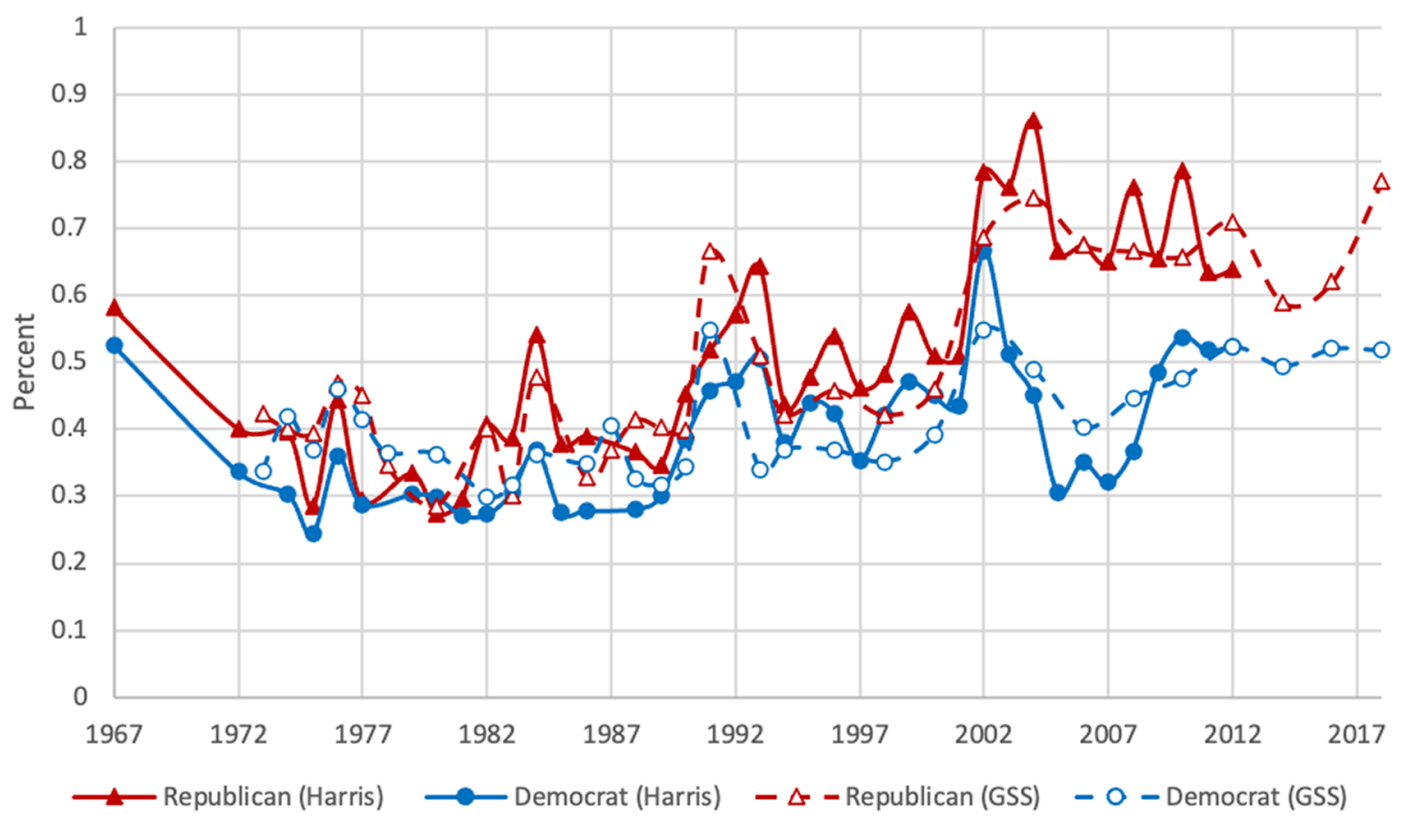

Note. Lines show the percentage of respondents reporting "a great deal" of confidence in the military in Harris and General Social Survey Polls. Thanks to David Burbach for sharing the data from which this figure was generated.

90). Public opinion thus features in the background of Feaver's theory: the less the public buys in to civilian supremacy, the greater are the potential costs of disciplining shirking military officers, the less likely civilians then are to punish them, and the less effectively civilian monitoring then produces military compliance. These theories' implicit reliance on supportive mass opinion becomes explicit in Schiff's "concordance theory," which sees agreement among officers, political elites, and the citizenry on the military's role as essential to forestalling the military's intervention in politics (Schiff 1995, 2009).

However, existing surveys of U.S. public opinion yield only limited insight into the public's views of civil-military relations. It is well known that the American public has a great deal of confidence in the U.S. armed forces. For at least the past twenty-one years, Americans have had more confidence in the U.S. military than in any other political or social institution. ${ }^{16}$ This trust has endured through two largely unpopular and unsuccessful wars in Afghanistan and Iraq (Burbach 2017, 2019). While Americans generally express confidence in the military, this has been especially true of Republicans-as figure 1 shows. The partisan gap grew substantially with the 2003 Iraq War, shrank at the start of the Obama administration, and then grew strikingly again after Trump's election in 2016. But is "confidence" in the U.S. military a useful stand-in for other substantive attitudes, such as deference to the armed forces? We do not know, because pollsters have only occasionally asked more detailed questions about Americans' views of civil-military relations.

Studies delving deeply into U.S. public opinion on civilmilitary relations have been rare. Responses to occasional survey questions from the 1940s through the 1990s suggested that the mass public did not share experts' commitment to civilian supremacy (Clotfelter 1973, 124-127; Feaver 2003, 40-42). However, in fall 1998 and spring 1999, the Triangle Institute posed a series of questions regarding the appropriate roles of civilian officials and military officers in decision-making and politics to a nationally representative sample of around 1,000 Americans and a convenience sample of military officers at various stages of career. This survey found that the professional military hewed more closely to democratic civil-military norms than did civilians. Just $7.9 \%$ of surveyed officers agreed to some extent that "high-ranking military officers," not "high-ranking civilian officials," should have "the final say on whether or not to use military force," but $44.4 \%$ of civilians felt that way. Few military officers (12.4\%) agreed that they should be allowed to "publicly criticize senior members of the civilian branch of government," but around one-third of Americans (33.7\%) thought so. The overwhelming majority of Americans$86.2 \%$ - thought it was "proper for the military to advocate publicly for the military policies it believes are in the best interests of the United States," and almost as many$83.7 \%$ —believed that "members of the military should be 
allowed to publicly express their political views like any other citizen"; many officers concurred on military affairs (67.9\% percent), but relatively few thought that right extended to the political arena (39.7\%; Davis 2001, 120-121). ${ }^{17}$ The Triangle Institute survey, however, is over two decades old, and it was conducted at a time of great tension between civilians and uniformed military, but also of relative international calm. It is unclear whether the Triangle Institute's findings still hold-after the United States embarked on a series of protracted wars after 2001, and after U.S. politics became far more polarized.

In 2013, as part of a larger survey, Schake and Mattis asked Americans to select one of four beliefs about civilian and military roles in the use of force. At one extreme was "when the country is at war, the President should personally direct both the broad objectives as well as the details of military plans." At the other lay "when the country is at war, the President should basically follow the advice of the generals." Three times as many respondents chose the latter highly deferential option (18\%) as the former (just $5 \%)$. The most popular response- $41 \%$ - came closest to the "normal theory" division of labor: "when the country is at war, the President should manage the broad objectives but leave the details of military plans to the generals." 18 While this question is revealing of Americans' views, it is limited in three respects. First, it does not probe respondents on the key issue of deference: whose judgment should determine policy when high-level civilian and military officials disagree. Second, it is framed as an ongoing military mission, and it is therefore not clear how survey-takers would respond to a prospective mission. Third, the question of civilian control is not restricted to the "objectives" versus the "details" of war-fighting, but extends to where the line is drawn between "means" and "ends" (Kemp and Hudlin 1992, 8-9). Additionally, while the authors ask other questions about civil-military relations-including military oversight, the credibility of military public information, and military endorsements of political candidates - these are often framed with respect to the mission in Afghanistan, which raises questions about these findings' generalizability. Schake and Mattis concluded that their survey indicates that the mass public has "a strong grasp of the fundamental principles on which the American model of civil-military interaction is based" (Schake and Mattis 2016a, 291). ${ }^{19}$ Our survey's design rectifies those limitations, and it reaches strikingly different, and less reassuring, conclusions about Americans' adherence to those "fundamental principles" of civilmilitary relations.

Finally, recent experimental work has yielded important insights into the U.S. public's deference to the military. Golby, Feaver, and Dropp find that the views of senior military leaders-particularly when they oppose a mission -impact public support for the use of force (Golby, Feaver, and Dropp 2018). Employing a conjoint experimental design, Jost and Kertzer find that Americans are more likely to endorse the policy recommendations of senior military officers than of civilian experts and those of advisers with military experience than of advisers without; they further show that Americans' respect for military officers' opinions extends to arenas well beyond the use of force (Jost and Kertzer 2019). However, neither paper confronts directly the core issue of deference: once the president has consulted with and received input about a prospective mission from senior military officers, but has nevertheless reached a different conclusion, whose view should become policy? Our survey asks respondents directly whether the military's judgment should trump that of the president when it comes to using force.

\section{The Survey}

To assess the American public's views on civil-military relations, we collected a sample of 1,921 U.S.-based respondents between May 31 and June 23, 2019, via Lucid. ${ }^{20}$ Lucid supplies respondents using an iterative process that matches gender, age, education, race, Hispanic origin, state, and region to parameters from the 2015 Census Bureau's American Community Survey. ${ }^{21}$ The survey poses a series of questions to gauge how Americans think about civil-military relations. Per the earlier discussion, it focuses on three concepts: (a) civilian supremacy on decisions regarding the use of force; (b) the boundaries of appropriate military intrusion into policy debate in public venues; and (c) the appropriate extent and subject of civilian oversight of the military.

Civilian supremacy. To ascertain respondents' attitudes toward civilian supremacy, we asked whether the president should approve a proposed military mission when senior military officers support the mission and, more pointedly, whether the president should approve the mission only if the president agrees with their judgment or even if the president disagrees. We also asked this question framed in the negative: whether the president should reject a proposed military mission when senior military officers object to it.

Because we wish to highlight the core dynamic of deference, we have intentionally departed from the traditional framing of survey questions about support for the use of military force. Deference to another goes well beyond due consideration of, or respect for, another's opinion. Philosophers associate deference with denying one's own right or capacity to make a moral judgment. When people are deferential to a particular authority, they voluntarily substitute the authority's judgment for their own. When I am deferential to a doctor, for instance, "the doctor's views do not outweigh mine; they replace mine" (Richards 1964; Soper 2002, 36 and passim). Because judges sometimes expressly defer to executive branch officials and agencies, legal scholars have considered deference, as both concept and practice. In that literature, deference means at a minimum "acceding to the views 
of others even when one's own personal judgment is that the recommended action is wrong." Put formally, "deference ... involves a decisionmaker (D1) setting aside its own judgment and following the judgment of another decisionmaker (D2) in circumstances in which the deferring decisionmaker, D1, might have reached a different decision" (emphasis original; Horwitz 2007-2008, 1073 and passim; Schauer 2008; Soper 2002, 7).

The central issue of deference is, therefore: should the national leader substitute the military's judgment for her own regarding whether and how to use military force?22 Healthy democratic civil-military relations expect national leaders to consult with senior military officers before ordering the use of force, and the military's expert advice may well influence the ultimate decision. But control is weakened if authorized civilians are expected to defer to the armed forces - that is, to replace their judgment with that of senior military officers. Other surveys - which ask respondents which adviser's recommendations they support (Jost and Kertzer 2019) or who should set the objectives and the details of ongoing wars (Schake and Mattis 2016b), or which prime respondents about the military's views of a prospective mission (Golby, Feaver, and Dropp 2018) — do not address this central dilemma of deference.

To generate a baseline of deference to expertise, we also posed these two questions with reference to civilian advisers. ${ }^{23} \mathrm{~A}$ third question involving military officers focused on whether the president should defer to senior military officers regarding how to employ force on the battlefield. To grasp the extent of respondents' general inclination to defer to the judgment of senior military officers, we generated a "Deference Index" that varies between 0 and 3 -with 3 representing the position of maximal deference. $^{24}$ To facilitate longitudinal comparisons, we also reproduced the 2013 Schake and Mattis question on deference.

Boundaries of advocacy. To grasp whether, on what issues, and to what extent Americans believe senior military officers should advocate publicly for particular policies, we asked respondents to express their agreement with a series of statements that varied in the advocates (senior military officers, retired senior military officers), the object of advocacy (policies not related to the military, military operations and policies), and the purpose of advocacy (in favor of certain operations and policies, against certain operations and policies).

Civilian oversight. To measure respondents' support for civilian oversight of the armed forces, we asked respondents how intense and frequent civilian scrutiny of military decisions should be with respect to nine different issues: the defense budget, weapons development, base closures, manpower policy, sexual harassment policy, force employment, the military justice system, training, and veterans' benefits. We created an "Oversight Index," based on an additive measure of respondents' expressed support for more frequent and intense oversight in each issue area. ${ }^{25}$

In addition, we sought to identify the reasons Americans do-or do not-trust military officers, and asked respondents how much they believe military officers know about international affairs-not specifically military affairs - compared to other decision-makers. Finally, we measured common individual-level covariates-political ideology, gender, race, age, level of education, income, military service, household military service, party identification, and political knowledge. We also included versions of three well-established psychological batteries: "blind patriotism," "right-wing authoritarianism," and "social dominance orientation." These are all correlated with, but distinct from, political conservatism (Schatz, Staub, and Lavine 1999; Van Hiel and Mervielde 2002). ${ }^{26}$

\section{Finding \#1: The U.S. Public's Views Are Not in Line with Democratic Civil-Military Relations Theory}

If the U.S. public adhered to the normative consensus among experts on democratic civil-military relations, large majorities would abjure deference to the armed forces and would oppose the military's open, public involvement in policy debate. But our survey reveals that the U.S. public is out of step with these consensus principles. Consider the most basic question: who decides when to use force. Per table 1, "if senior U.S. military officers approve of a proposed military mission," nearly $40 \%$ of respondents think the president should give his blessing "even if the president thinks the mission not worthwhile." Even more are deferential, however, if the scenario is framed in the negative. "If senior U.S. military officers object to a proposed military mission," over $50 \%$ of respondents think the president should reject the mission "even if the president thinks the mission worthwhile." In sum, depending on how the question is framed, either a very substantial minority or a slim majority of Americans believes that the judgment of the professional military should replace that of the nation's elected leader. The "normal theory" of civil-military relations would expect, and approve of, deference when it comes to battlefield tactics, yet Americans are only slightly more deferential to the military on tactical matters. "If senior U.S. military officers advise using U.S. forces on the battlefield in a particular way," just over $45 \%$ of respondents say that "the president should use U.S. forces as they advise- even if the president disagrees." In short, as table 1 reveals, when it comes to when and how to use military force, Americans' views are not in line with the principle of civilian supremacy. Large numbers, sometimes a majority, think the president should override his own judgment and simply do what senior military officers want. 
Table 1

Deference to the military and the use of force

If senior U.S. military officers object to a proposed military mission, then the president should:

\begin{tabular}{lr}
\hline & Total \% \\
\hline - reject the proposed mission-even if the president thinks the mission worthwhile. & 50.29 \\
- reject the proposed mission-only if the president agrees that the mission is not worthwhile. & 49.71 \\
If senior U.S. military officers approve of a proposed military mission, then the president should: & Total \% \\
\hline & 39.46 \\
\hline & 60.54 \\
- approve the proposed mission-even if the president thinks the mission not worthwhile. & Total \% \\
If senior U.S. military officers advise using U.S. forces on the battlefield in a particular way, & 45.86 \\
then the president should: & 54.14 \\
\hline
\end{tabular}

Americans also seem to have few reservations about the military's involvement in public debate over policy. A majority of respondents- $56.1 \%$ - agree to some extent that "senior military officers should advocate publicly for military operations and policies they favor," compared to just $17.2 \%$ who disagree to any extent (figure 2). That number falls only slightly, to $50.3 \%$, when the statement is framed in the negative: "Senior military officers should advocate publicly against military operations and policies they do not favor." A plurality even endorses military public advocacy on matters that "they believe are in the country's best interest, even if the policies are not related to the military": $40.9 \%$ agree with this statement, versus $29.3 \%$ who disagree. ${ }^{27}$ While active-duty U.S. military officers rarely express publicly their policy views, Americans are routinely exposed to retired generals praising or criticizing the nation's elected leadership. Per figure 2, respondents draw no meaningful distinction between active-duty and retired generals in this regard. They endorse retired officers' advocacy on military matters to roughly the same degree as they do active-duty officers (55.7\% approve); on non-military affairs, their approval is moderately higher than for active duty $(48.9 \%) .^{28}$

While Americans trust the military, that trust does not appear to be rooted in the belief that officers are "apolitical" (contra Hill, Wong, and Gerras 2013; King and Karabell 2003). Consistent with past polls, just $15.9 \%$ of this survey's respondents express any distrust of military officers. ${ }^{29}$ However, when asked to identify the reason for their trust, just under $10 \%$ of those who trust do so because "military officers do not get involved in politics." In fact, nearly one-quarter of respondents
(23.5\%) disagree with the statement, "I trust military officers because they are non-political," and only $51.2 \%$ agree. That is far less than the support respondents give to any of the three other provided reasons for trust: professional competence, ethical commitments, patriotism. ${ }^{30}$ In short, while the survey data suggest that Americans have only modest faith that military officers stay out of politics, that has little apparent impact on their trust in military officers.

The one area in which Americans are largely in line with traditional norms is oversight. In general, more Americans opt for the intense-and-frequent-oversight side of the scale than the light-and-occasional side. Nothing would seem to fall more within the military's zone of professional expertise than the training of soldiers, but even here a slim plurality of respondents $(42.1 \%)$ prefer more oversight, compared to $40.1 \%$ who prefer less. Even more $(43.6 \%)$ want greater oversight over the use of forces on the battlefield, compared to the $36.1 \%$ who want less. Calls for frequent and intense oversight are, not surprisingly, greatest-over $60 \%$ - on widely publicized issues on which the military has seemed incapable of governing itself: sexual harassment policy and the treatment of veterans. ${ }^{31}$ Initially, there appears to be a tension between deference and oversight: deference entails substituting officers' judgment for that of civilians, whereas oversight implies that civilians' judgment ultimately trumps that of officers. However, the survey's questions do not probe deeply into why and to what degree respondents support oversight of the military. Democratic civil-military relations mandate significant oversight to ensure that military officers do not deviate from civilians' 


\section{Figure 2}

\section{Active-duty and retired military officers and policy advocacy}

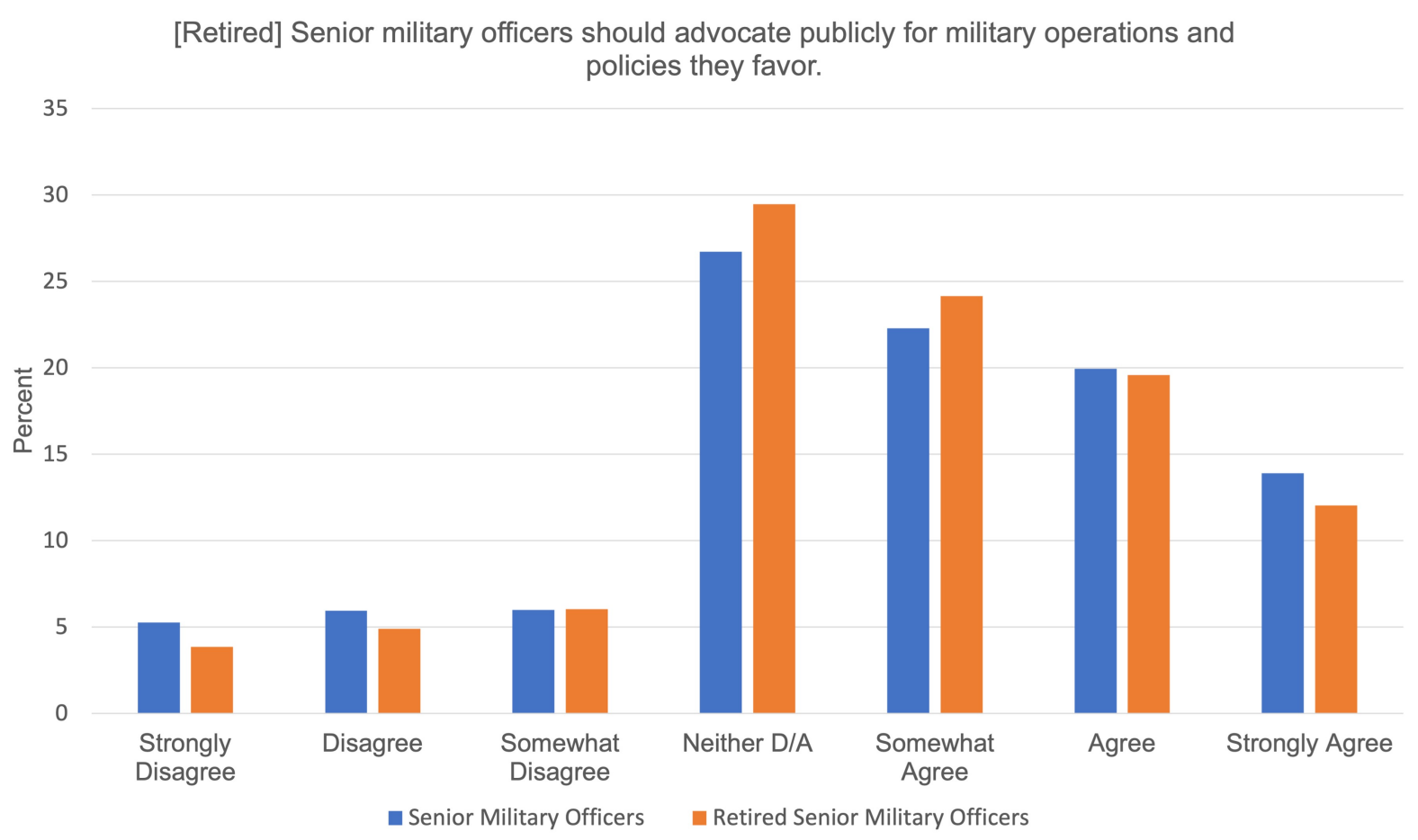

will and to hold officers accountable if they do. But respondents who endorse deference to the armed forces may back civilian oversight to help the military honor its own commitments and standards or to promote civilian supremacy only at the extremes-such as, to prevent military disobedience of civilians' express orders.

The next section delves into significant differences among respondents, but that nuanced analysis should not lead readers to lose sight of the disturbing big picture. A large proportion, and sometimes a majority, of Americans-across demographic and ideological groups—seem not to subscribe to the tenets of democratic civil-military relations. They are often inclined to show deep deference to senior officers' preferences regarding not just how to employ force on the battlefield, but whether to employ force to advance national aims. Nor are they worried by the professional military's public involvement in policy debate. By the standards of the normative consensus, Americans' commitment to democratic civil-military relations is weak.

\section{Finding \#2: In Civil-Military Relations, Too, Politics Trumps Principle}

The theory of democratic civil-military relations is expressly normative. To the extent that principle governs attitudes toward civil-military relations, so should the ideological positions that undergird people's beliefs about politics. If that were true, political conservatives would be more deferential toward the armed forces and less sensitive to officers' intrusion into policy debate. For conservatives, the military is the state institution that most epitomizes the ideals they cherish: in-group loyalty and integrity, selfsacrifice, and obedience to authority. People who trust an institution are also more likely to defer to its leading members' judgment and to wish to grant that institution autonomy and to minimize intrusive oversight of it. Political liberals conversely would be less deferential to the military and more sensitive to officers' intrusion into policy debate (Krebs and Ralston 2020).

However, this survey's bivariate results largely point in precisely the opposite direction. In June 2019, when the survey was fielded, trust in the military was, surprisingly, associated in bivariate analysis with less deference on strategic, and to a lesser extent tactical, matters. Whereas $38.4 \%$ of those who greatly trust the military believed that presidents should, regardless of their own assessment, follow senior officers' lead in approving a proposed mission, $47.2 \%$ of those who greatly distrust the military adopted that stance. While $48.1 \%$ of extreme trusters called for deference to senior officers' objections to a prospective military mission, a whopping $59.6 \%$ of extreme distrusters said the same. ${ }^{32}$ On its face, this 
Table 2

Deference to the military: Partisan comparisons

If senior U.S. military officers approve of a proposed military mission, then the president should:

\begin{tabular}{|c|c|c|}
\hline & $\begin{array}{l}\text { Democrats and Democratic- } \\
\text { Leaning Independents, \% }\end{array}$ & $\begin{array}{l}\text { Republicans and Republican- } \\
\text { Leaning Independents, \% }\end{array}$ \\
\hline \multirow[t]{3}{*}{$\begin{array}{l}\text { - approve the proposed mission-even if the } \\
\text { president thinks the mission not worthwhile. } \\
\text { - approve the proposed mission-only if the } \\
\text { president agrees that the mission is worthwhile. }\end{array}$} & $\begin{array}{l}46.54 \\
53.46\end{array}$ & $\begin{array}{l}30.26 \\
69.74\end{array}$ \\
\hline & ed military mission, then the $p$ & esident should: \\
\hline & $\begin{array}{l}\text { Democrats and Democratic- } \\
\text { Leaning Independents, \% }\end{array}$ & $\begin{array}{l}\text { Republicans and Republican- } \\
\text { Leaning Independents, \% }\end{array}$ \\
\hline $\begin{array}{l}\text { - reject the proposed mission-even if the } \\
\text { president thinks the mission worthwhile. } \\
\text { reject the proposed mission-only if the presi- } \\
\text { dent agrees that the mission is not worthwhile. }\end{array}$ & $\begin{array}{l}57.97 \\
42.03\end{array}$ & $\begin{array}{l}40.31 \\
59.69\end{array}$ \\
\hline
\end{tabular}

observed negative relationship is exceedingly puzzling: why were those who most trust military officers least likely to defer to their judgment?

The answer seems to be, in a word, politics. In 2019, Republicans and Trump supporters were more likely to trust the military. Consistent with their ideological predispositions, they were less likely to demand frequent and intense oversight of the military. ${ }^{33}$ But their warmth toward the military evaporated when they realized that the preferences of the generals might trump those of Trump. Therefore, Republicans and Trump approvers adopted a relatively non-deferential attitude toward the military. They wanted Trump to have free rein, unconstrained by senior military officers. Democrats and Trump disapprovers were more likely to distrust the military, but they distrusted Trump even more. They were deferential to the armed forces because they hoped the military could act as a check on the president, whose policies they detested, whose judgment they found suspect, and whose impulsiveness they feared.

Per table 2, 46.5\% of Democrats and Democraticleaning independents said that, if senior U.S. military officers approve of a proposed military mission, the president should do what they say, contrary to his own judgmentcompared to $30.3 \%$ of Republicans and Republicanleaning independents $(t=-7.34 ; \mathrm{p}<0.000)$. When framed in terms of military objection to a proposed mission, deference generally rose, but the partisan differences remained: $58.0 \%$ of Democrats and Democratic-leaning independents adopted the more deferential position, compared to $40.3 \%$ of Republicans and Republican-leaning independents $(t=-7.7921 ; \mathrm{p}<0.000)$. The U.S. public's attitudes toward civil-military relations thus reflect the extraordinary partisan polarization of U.S. politics over the last quarter-century. It was apparently too much to hope that public opinion on the military would remain immune to these pressures (see also Burbach 2019; Golby 2011, ch. 3; Robinson 2018, ch. 3).

The pattern emerges even more clearly through the lens of respondents' approval of Trump's performance as president. As table 3 shows, respondents who strongly disapprove of the president were the most deferential to the armed forces, and those who strongly approve were the least: depending on the question, the former were $60 \%$ $80 \%$ more likely to adopt a deferential stance. ${ }^{34}$ These results are borne out as well in the Deference Index. Figure 3 displays the stark effects that respondents' partisan affiliations and views of the president had on their inclination to military deference: Democrats and Democratic-leaning independents, along with Trump disapprovers, scored higher on the index-that is, they were more deferential to the military-than Republicans and Republican-leaning independents as well as Trump approvers. ${ }^{35}$ These partisan effects, however, seemed to be stronger among Republicans and Republican-leaning independents, and Trump approvers, whose lines in figure 3 slope consistently downward. In contrast, the lines of Democrats and Democraticleaning independents, and Trump disapprovers, slope upward, but then plateau — suggesting that they were not as prepared to sacrifice their ideological commitments and embrace deference to the military.

The same pattern manifests in attitudes toward senior officers' policy advocacy in the public domain. If respondents were motivated by ideology, one would expect liberals to be more critical of officers' advocacy. This was the case in past surveys, when partisan and ideological interests aligned. ${ }^{36}$ But, in our 2019 survey, when partisan and ideological interests were not in accord, Democrats were 


\section{Table 3}

\section{Deference to the military and Trump approval}

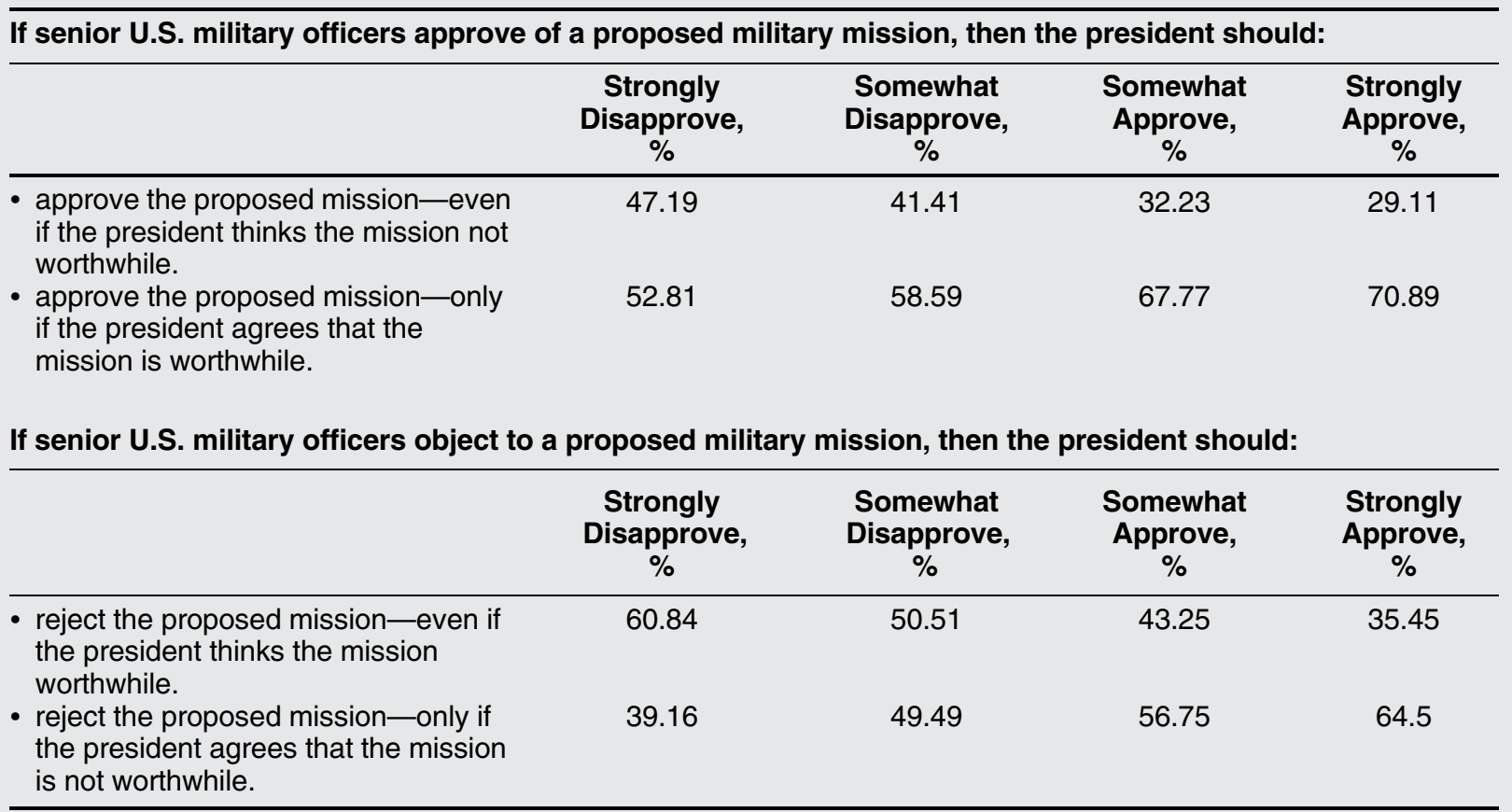

\section{Figure 3}

\section{Deference index scores by party identification and Trump approval}

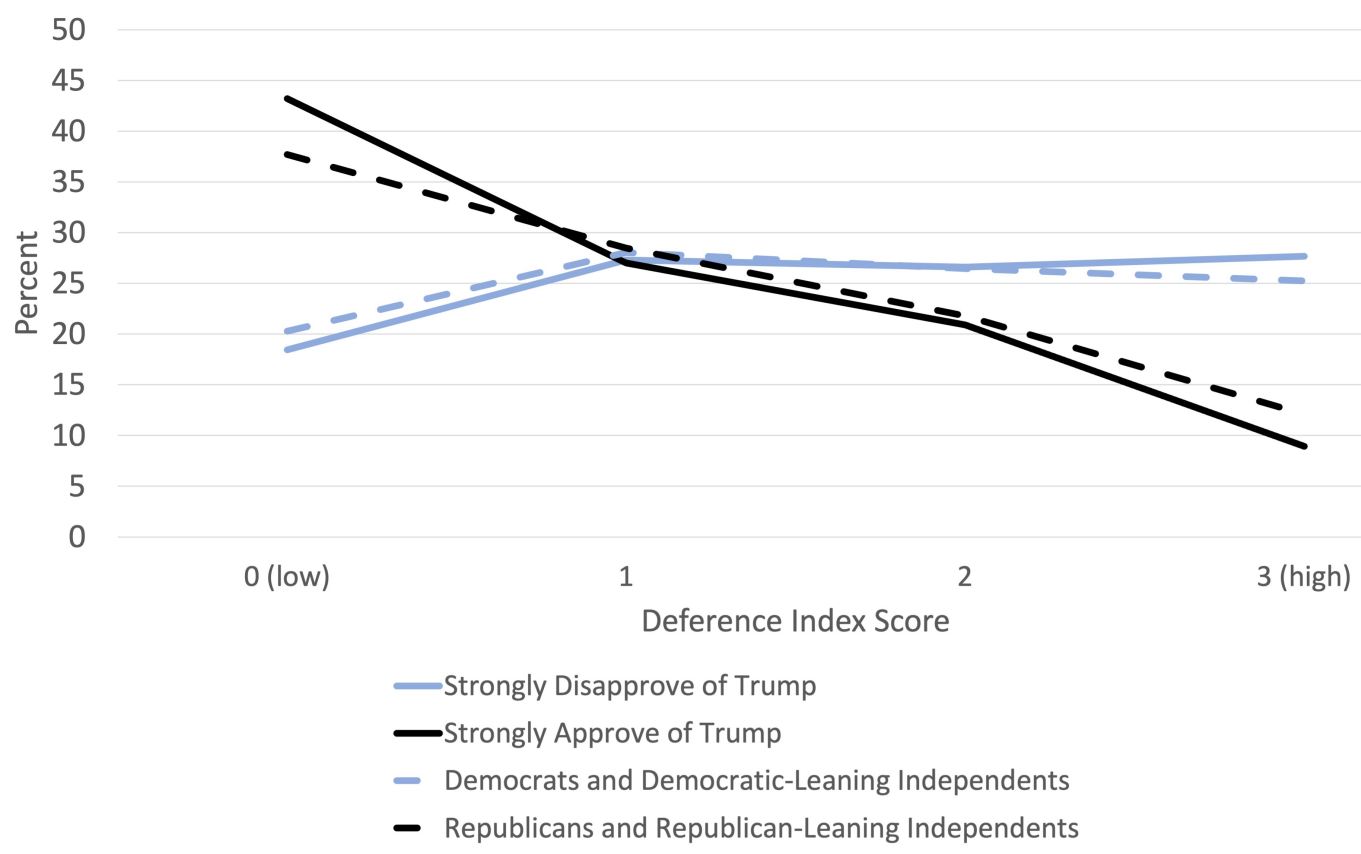

more likely to agree with statements endorsing military advocacy and less likely to disagree. For instance, 55.2\% of Democrats agreed that "senior military officers should advocate publicly against military operations and policies they do not favor," compared to $49.6 \%$ of Republicans;
$25.5 \%$ of Republicans disagreed, compared to just $17.8 \%$ of Democrats. The same partisan pattern holds regarding whether "senior military officers should advocate publicly for policies they believe are in the country's best interest, even if the policies are not related to the military." Similarly, 


\section{FIGURE 4}

\section{Predicted deference index scores: coefficient plot}

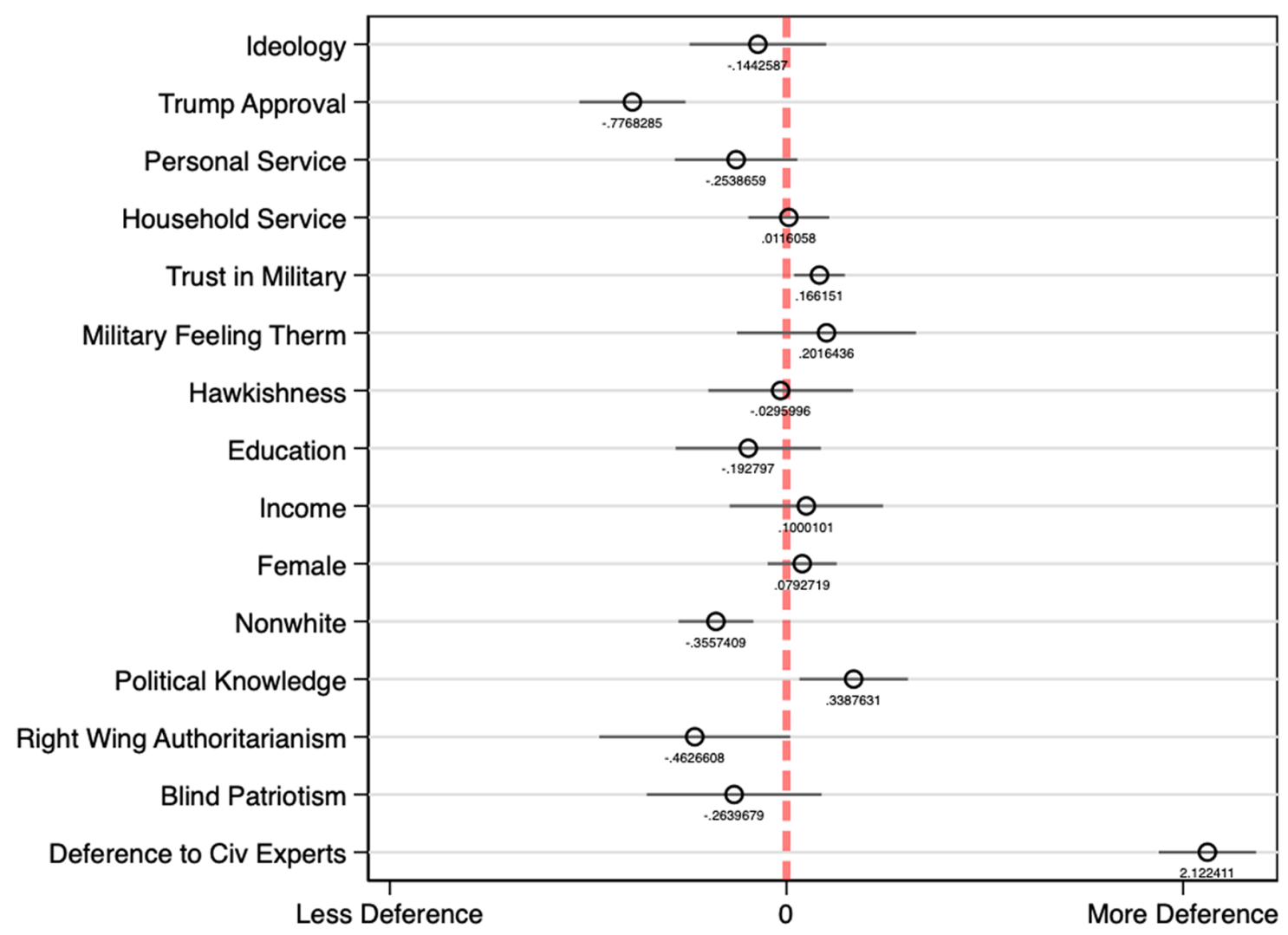

those who strongly approve of Trump as president were more likely to disagree with pro-advocacy statements and less likely to agree than those who strongly disapprove. ${ }^{37}$ However, the effects of partisanship and Trump approval on military advocacy were not quite as clear or substantial as their effects on deference. We suspect this is because the advocacy statements never explicitly mention the president, and therefore any conflict between military and presidential preferences can only be inferred.

The findings on deference to the military hold in multivariate analysis. Figure 4 displays the impact of various variables on respondents' Deference Index scores. ${ }^{38}$ In other statistical analyses, political conservatism, Republican partisan identity, and Trump approval are all significantly associated on their own with less deference. ${ }^{39}$ However, including either party identification or Trump approval alongside political ideology renders the latter variable insignificant. ${ }^{40}$ In figure 4, approval of Trump has the largest negative substantive effect on deference to the military, while political ideology is statistically and substantively insignificant. Respondents' general respect for expertisereflected in their deference to civilian experts- has far and away the largest positive substantive effect on deference to the military. Trust in the military is consistently positive and significant—as one would expect—but its substantive effect is also small. Revealingly, right-wing authoritarianswho are especially warm toward this institution and who should be deferential to its leading members-are significantly less deferential in figure $4 .{ }^{41}$ Among other controls, nonwhite respondents are less deferential, and politically knowledgeable respondents are unexpectedly more so. The multivariate analyses confirm that ideological commitments are not the chief drivers of respondents' deference to the military. Partisan identity and attitudes toward the president matter more.

Both partisan identity and Trump approval also have substantively significant effects on deference. Figure 5 displays the probability that a respondent achieves a high Deference Index score (2 or 3 ), conditional on their selfreported partisan identification or Trump approval. In 2019 there was a $54 \%$ chance that a respondent who strongly disapproves of Trump would be highly deferential to the military, compared to just a $30 \%$ chance for a respondent who strongly approves. Put differently, in 2019 , strong Trump disapprovers were $80 \%$ more likely to be highly deferential than strong Trump approvers. The effects were very similar with political partisanship: moving from one extreme (strongly Democratic) to the other (strongly Republican) translated into a $42 \%$ lesser likelihood of the respondent being highly deferential. 


\section{Figure 5}

\section{Probability of deferring to the military across levels of Trump approval and party identification}
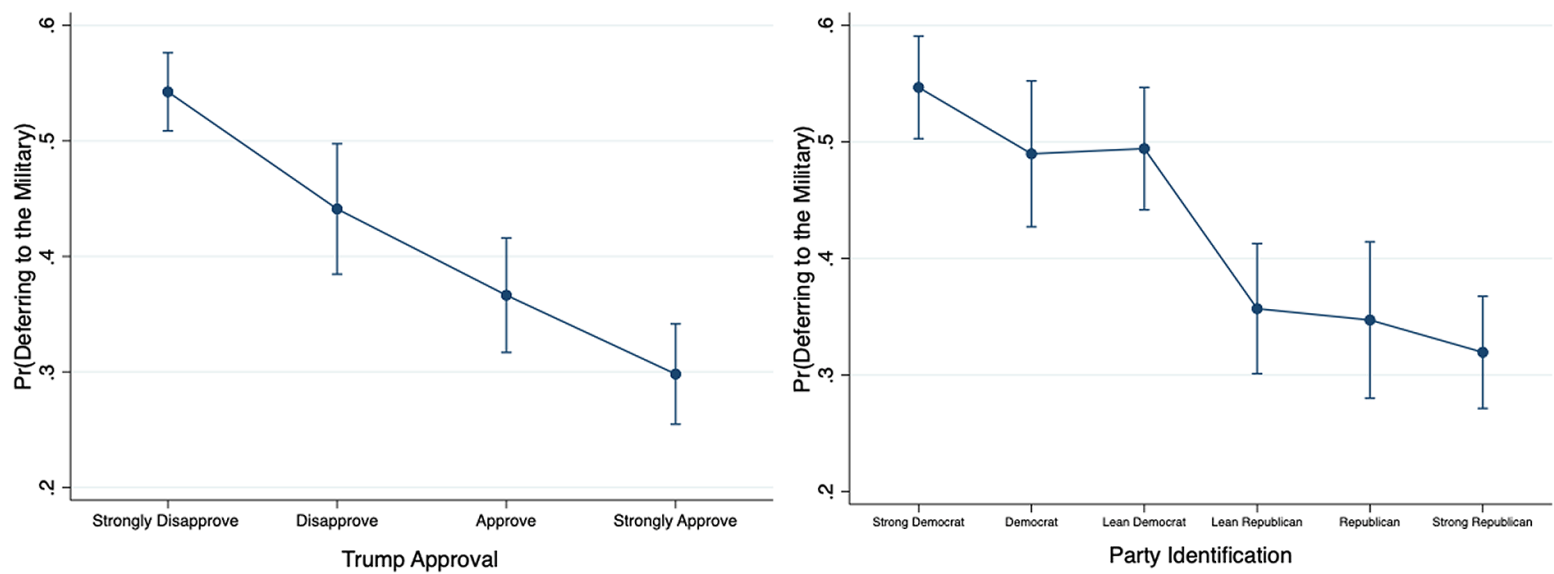

Note. Predicted probability (expressed as $95 \%$ confidence intervals) of scoring 2 or 3 on the Military Deference Index. The figures are based on a binary dependent variable. Models include no controls.

Table 4

Schake and Mattis deference question (2013)

\begin{tabular}{|c|c|c|c|}
\hline Response & $\begin{array}{c}\text { Democrat, } \\
\%\end{array}$ & $\begin{array}{c}\text { Independent, } \\
\%\end{array}$ & $\begin{array}{c}\text { Republican, } \\
\%\end{array}$ \\
\hline $\begin{array}{l}\text { - When the country is at war, the President should personally direct } \\
\text { both the broad objectives as well as the details of military plans }\end{array}$ & 7 & 5 & 1 \\
\hline $\begin{array}{l}\text { When the country is at war, the President should personally direct } \\
\text { the broad objectives and manage some of the details of military } \\
\text { plans }\end{array}$ & 27 & 16 & 3 \\
\hline $\begin{array}{l}\text { - When the country is at war, the President should manage the broad } \\
\text { objectives but leave the details of military plans to the generals }\end{array}$ & 35 & 39 & 56 \\
\hline $\begin{array}{l}\text { - When the country is at war, the President should basically follow the } \\
\text { advice of the generals }\end{array}$ & 9 & 20 & 34 \\
\hline - Not sure & 22 & 20 & 7 \\
\hline
\end{tabular}

Table 5

Replication of Schake and Mattis deference question (2019)

\begin{tabular}{|c|c|c|c|}
\hline Response & $\begin{array}{c}\text { Democrat, } \\
\%\end{array}$ & $\begin{array}{l}\text { Independent, } \\
\%\end{array}$ & $\begin{array}{l}\text { Republican, } \\
\%\end{array}$ \\
\hline $\begin{array}{l}\text { - When the country is at war, the President should personally direct } \\
\text { both the broad objectives as well as the details of military plans }\end{array}$ & 11 & 12 & 18 \\
\hline $\begin{array}{l}\text { - When the country is at war, the President should personally direct } \\
\text { the broad objectives and manage some of the details of military } \\
\text { plans }\end{array}$ & 15 & 11 & 18 \\
\hline $\begin{array}{l}\text { When the country is at war, the President should manage the broad } \\
\text { objectives but leave the details of military plans to the generals }\end{array}$ & 38 & 45 & 46 \\
\hline $\begin{array}{l}\text { - When the country is at war, the President should basically follow the } \\
\text { advice of the generals }\end{array}$ & 28 & 23 & 11 \\
\hline - Not sure & 8 & 8 & 6 \\
\hline
\end{tabular}


To test these claims regarding the effects of ideology and partisanship, we compared the responses to Schake and Mattis' 2013 deference question to the replicated question in our 2019 survey. The results, in tables 4 and 5, are striking. In 2013, virtually no Republican respondents adopted a position of maximal civilian supremacy: just $1 \%$ said that "when the country is at war, the President should personally direct both the broad objectives as well as the details of military plans." In 2019, 18\% of Republicans endorsed this view. In 2013, just 9\% of Democrats opted for extreme deference: "when the country is at war, the President should basically follow the advice of the generals." In 2019, 28\% of Democrats chose this option. In 2013, $34 \%$ of Republicans preferred the most deferential position, but just $11 \%$ did in 2019. In a multinomial logistic regression analysis of the 2013 results, we find that both political conservatives and Republicans were significantly less likely to select the first three civil-military alternatives relative to the last- that is, the position of greatest deference. Analysis of the 2019 results finds the inverse: both conservatives and Republicans were significantly more likely to select the first three alternatives relative to the last. ${ }^{42}$ Conservatives' and Republicans' warmth toward and trust of the armed forces had not waned between 2013 and 2019-just the opposite. What had changed was the partisan affiliation of the president.

\section{Alternative Explanations and Interpretations}

We argue that public support for democratic norms of civil-military relations is in poor shape in the United States. Large swaths of the U.S. public seem quite willing to replace the judgment of their elected officials with that of the military and to urge military officers to wade into public debates on policy. Many Americans are unprepared to guard the guardians.

Perhaps, however, these results reflect not respondents' deference to the military, but their hawkishness. If respondents care more about policy outcomes than about the niceties of civilian supremacy, maybe hawkish respondents wish to empower the military because they presume officers share their policy preferences. However, respondents' hawkishness would then be a significant predictor of their answers to the three individual deference questions. Yet that is not the case: hawks are not significantly more supportive of the president overruling the military when he approves of the mission, nor are they significantly more deferential to the military when its leadership supports using force. ${ }^{43}$

Perhaps, though, hawkish respondents' predilection for employing force helps explain why they "flip" from a nondeferential stance (when senior U.S. military officers object to the mission) to a deferential one (when senior U.S. military officers approve of it). Indeed, we find that hawkishness is a significant predictor of "flipping."
However, even in these cases, respondents' attitudes toward the president and political ideology remain significant: hawks who strongly approve of Trump and who selfidentity as conservatives are more likely to remain consistently non-deferential to the military. Moreover, respondents' dovishness does not seem to help explain why some "flip" from a non-deferential stance (when senior U.S. military officers approve of the mission) to a deferential one (when senior U.S. military officers object to it). ${ }^{44}$ In short, the effects of hawkishness are highly circumscribed, and deference to the armed forces is independent of respondents' general attitudes toward the use of force.

Alternatively, perhaps Americans' deference to the armed forces reflects the reality that military service today is distant from most Americans' lives. ${ }^{45}$ This claim implies that those more familiar with the military-veterans and maybe their family members - should adhere more closely to the normative ideal. However, our survey data do not support this alternative explanation. We find that veterans are as deferential as non-veteran civilians to senior military officers regarding when to use force; they are less deferential only regarding how to use force. In other words, their view-even more than that of civilians-is antithetical to the "normal theory" of civil-military relations. ${ }^{46}$ Veterans are also significantly less supportive of oversight of the military-again contrary to civil-military norms. ${ }^{47}$ Meanwhile, the views of military household members are, generally speaking, indistinguishable from those of other civilians on critical questions of deference to and oversight of the military. ${ }^{48}$

We have further argued that political loyalties-more than ideology-significantly shape attitudes toward civilmilitary relations. Perhaps, though, members of the U.S. public have become deferential to the armed forces out of a different principled commitment: left-liberal Americans in particular may have believed in 2019 that Donald Trump represented a singular threat to democratic norms, and they may therefore have turned to the military as a backstop to democratic backsliding. We are skeptical, however, of this Trump-as-threat-to-the-republic alternative explanation. First, concern about the health of the nation's democratic institutions has long been related to party affiliation —as far back as 1996, when the American National Election Study first started asking people if they were "satisfied with the way democracy works in the United States." In general, those whose party won the last presidential election think U.S. democracy is in better shape than those whose party lost. ${ }^{49}$ Weak faith in democracy's present practice may be another mechanism through which partisan politics shape attitudes toward civil-military relations, but it is not an independent explanatory account.

Second, while this alternative explanation may conceivably shed light on why Democrats and Trumpdisapprovers were more deferential to the armed forces 
in 2019 than in 2013, it cannot explain why Republicans and Trump-approvers became less deferential over that span. By its logic, the many Republicans who believe the Trump administration a stalwart defender of democracy had no reason to shift their view of civil-military relations. Moreover, as noted earlier with reference to figure 3, the Trump-threat argument would expect the strongest partisan effects to be concentrated among Democrats and Democratic-leaning independents. Yet we find the opposite. These respondents are ambivalent about deferring to the military; as a result, they are evenly spread across three of the four levels of the Deference Index. Republicans and Republican-leaning independents are far less equivocal, contrary to this alternative argument.

Perhaps though a different principled commitment underlies these results: maybe many respondents welcome senior officers' open intervention in policy debate because they believe deeply in democratic deliberation and transparency, wish to be better informed, and therefore want to hear from all relevant parties, including military officers. Were this the case, liberals, who more deeply value liberaldemocratic institutions, ${ }^{50}$ would be more supportive of officers wading into public policy debates. Conservatives, who rank higher on the authoritarianism and blindpatriotism scales (Schatz, Staub, and Lavine 1999, 167; Van Hiel and Mervielde 2002, 969), and authoritarians and nationalists, who place relatively little value on democracy, would be less supportive (de Figueiredo and Elkins 2003, 177, 179). This is precisely what we find: liberals and Democrats were more supportive in 2019 of officers' public policy advocacy. Note that this unusual interpretation of liberals' preferences means that partisan and ideological interests aligned in 2019, making it impossible to separate the two accounts. However, if we are right, after Democrat Joe Biden entered the Oval Office in January 2021, Democrats' views of military intrusion into policy debate would shift-whereas, by this ideological account, they would not. Moreover, our political account seems more plausible because Democrats in 2019 supported deference toward the military, and it is extremely hard to square that deferential stance with any variant of liberal ideology.

\section{Conclusion}

Even the widely trusted U.S. military cannot escape the nation's deeply polarized politics. Although Americans of all stripes generally hold the armed forces and its officers in high regard, partisanship is now-and perhaps has long been-a key driver of Americans' attitudes on these basic questions. Principled devotion to democratic civil-military relations, we have discovered, is rare, and in 2019 Trump's supporters were oddly less deferential to the military-and more in line with the civil-military normative consensusthan were his detractors. If a more "normal" Republican had ascended to the presidency in 2016, would we have witnessed the same shift toward military deference among Democrats? We suspect so, though our data cannot offer a conclusive answer. At least now, thanks to this article, we are asking the question. We make one strong prediction: with Democrat Joe Biden in the White House since January 2021, we expect partisans' stances on deference and military politics to flip yet again.

What is to be done? The answer depends on why Americans' normative views of civil-military relations diverge so dramatically from what democratic theory demands. This is an important research question, about which we can only speculate. Perhaps the problem lies partly in civics training. It seems likely that few Americans have thought deeply about how to guard the guardians. As much as military officers need to have proper norms of democratic civil-military relations inculcated, so does the average citizen. Democratic civil-military relations should, like the separation of powers, be a part of every high school civics class and indeed of citizens' lifelong civics education. ${ }^{51}$ However, we are wary of putting too much weight on socialization. If socialization were so powerful, then veterans would be stronger proponents of democratic civilmilitary relations, yet as discussed earlier, our evidence runs contrary to this claim. ${ }^{52}$ Recent survey data show that even West Point cadets, despite their intense and active socialization, do not endorse the principles of civilian supremacy (Brooks, Robinson, and Urben 2020). Lifelong education in democratic civil-military relations can help, but its absence is probably not responsible for our current straits.

More likely a significant part of the problem lies in rampant militarism in modern America, sustained by the nation's elites. Militarism is woven into America's everyday practices and national rituals as well as its political discourse (Bacevich 2005; Enloe 2000; Lutz 2001; Mann 1987; Millar 2019b): politicians routinely and exclusively narrate soldiering in terms of heroism, sacrifice, and patriotism, rather than professionalism, and they regularly declare their "support for the troops," even when criticizing ongoing missions (Krebs 2009; Millar 2019a). Deference to the military may derive from a deep tension between this dominant militaristic public narrative of soldiering and the modern military's market-based mode of recruitment. In the age of the conscripted mass army, the citizen-soldier willingly performing his duty thereby demonstrated his civic virtue, but he was no more virtuous than the millions of others who obeyed the call to the colors. When the draft ended, soldiers' reputation for virtue should have evaporated. The contracted professional may be highly skilled, but she is not virtuous. But the militaristic public narrative, by affirming that the citizen-soldier was embodied in the professional soldier, transformed the latter into a figure that combined both extraordinary virtue and great expertise. Our survey finds that belief in the U.S. officer corps' patriotism and 
competence is axiomatic in modern America. Very few question that "military officers put the interests of the country first," and even fewer think they are "not good at what they do." 53 The combination is formidable. A patriotic officer's heart is in the right place, but good intentions are never enough. A competent officer's professional judgment should be carefully weighed, but she may also be corrupt. However, if officers are unusually patriotic and unusually competent, and if politicians and bureaucrats are venal or ignorant, it is no wonder that many Americans are convinced that the preferences of officers should govern and that officers should freely and publicly weigh in on policy matters.

Building public support for democratic civil-military relations must start with brave leadership challenging the nation's militarist hegemony. Rather than encourage unquestioning deference to the military, politicians should model respectful skepticism. Rather than reflexively thanking soldiers for serving heroically, politicians should thank them for serving democratically-that is, for obeying the will of the people and their elected representatives. Rather than reproduce the mythology of the citizensoldier, politicians should speak more honestly about what drives soldiers and officers, about their foibles as well as their strengths. Politicians may even find that the nation's military men and women would welcome being taken down a notch. ${ }^{54}$

But brave leadership will not suffice to securely install civilian supremacy. Militarism's firm grip will be loosened only if there is also change from below. Democracy demands a certain degree of popular civic virtue. As the perfectly named U.S. federal judge Learned Hand warned, amidst the Second World War, "liberty lies in the hearts of men and women; when it dies there, no constitution, no law, no court can save it" (Hand 1977, 190). So does civilian control over the military.

\section{Acknowledgment}

For helpful feedback on earlier drafts of this article, the authors are grateful to audiences at Bar Ilan University, the London School of Economics, and the 2019 Conference of the Inter-University Seminar of Armed Forces and Society. They also thank, for their comments, Mark Bell, Avishay Ben Sasson-Gordis, Lindsay Cohn, Jonny Hall, Kate Millar, Mike Robinson, Chiara Ruffa, Jennifer Spindel, Jeremy Teigen, and Ariel Zellman. Finally, they thank the University of Minnesota, through its Grant-in-Aid of Research, Artistry, and Scholarship program, for its support of this research.

\section{Notes}

1 Carter, Phillip, and Loren DeJonge Schulman. 2016. "Trump Is Surrounding Himself with Generals. That's Dangerous." Washington Post, November 30;
Hartung, William D. 2017. “Trump's Obsession with Generals Could Send Us Straight into War with Iran." The Nation, March 6; Mann, James. 2017. "The Adults in the Room." New York Review of Books, October 26. For a contrary view, see Schake, Kori. 2016. "All the President's Generals." Foreign Policy. December 3.

2 See, among others, Ricks, Tom. 2016. "Will the Generals Obey Trump?" Foreign Policy, November 16; Sagan 2017; Feaver, Peter. 2016. "Will the Military Obey President Trump's Orders?” Foreign Policy, February 29.

3 Barno, David, and Nora Bensahel. 2019. "The Increasingly Dangerous Politicization of the U.S. Military." War on the Rocks, June 18; Carter, Phillip. 2018. "The Military Is Not a Political Prop." New York Times, February 8; Exum, Andrew. 2017. "The Dangerous Politicization of the Military." Atlantic, July 24.

4 Kaplan, Fred. 2020.“The Officers' Revolt.” Slate, June 3; Stracqualursi, Veronica. 2020. "The Prominent Former Military Leaders Who Have Criticized Trump's Actions over Protests." cnn.com, June 5. See, among others, Mullen, Mike. 2020. "I Cannot

Remain Silent." Atlantic, June 2; Mattis, James. 2020 "In Union There Is Strength." June 3 (https://www. npr.org/2020/06/04/869262728/read-the-fullstatement-from-jim-mattis); Stavridis, James. 2020. "I Spent My Career in the U.S. Navy. The U.S. Military Must Stand Up for Its Soul in This Moment.” Time, June 3 .

5 For key works on the classic civil-military problematique, see Huntington 1957; Janowitz 1960; Finer 1962; Desch 2001; Feaver 2003; Schiff 2009. For updates, extensions, and applications, see, among many others, Avant 1994, 2005; Brooks 2008, 2019; Nielsen and Snider 2009; Recchia 2015; Cohn, Coletta, and Feaver 2018.

6 For instance, research in wartime ethics shows how far the mass public's views depart from the just-war tradition; see Sagan and Valentino 2017, 2018. But that tradition expressly sought to elevate humanity-it did not assume that its arguments were "natural." Nor does the mass public have nearly as much exposure to the just-war tradition as to the folk definition of democracy.

7 See similarly Welch 1987; Hendrickson 1988. See also Betts 1977; Desch 2001, 2007.

8 For a thorough critique, see Brooks 2020.

9 See also Janowitz 1960, 417-442.

10 Janowitz saw this as a good thing for democratic control of the armed forces. See Janowitz 1960.

11 On the ways officers can and do engage in politics, but defending the normative consensus, see Brooks 2009, 2013. For moderate dissenting views, see Snider 2008; 
Golby 2015. For rare statements defending overt military involvement in policy debate, see Owens 2015; Coletta and Crosbie 2019.

12 See DCAF, Geneva Centre for Security Sector Governance (https://www.dcaf.ch/); United Nations Peacekeeping, Security Sector Reform. 2008. "Securing Peace and Development: The Role of the United Nations in Supporting Security Sector Reform." Report of the Secretary-General, January 23, A/62/659-S/2008/39 (https://peacekeeping.un. $\mathrm{org} / \mathrm{en} / \mathrm{security}$-sector-reform).

13 For a powerful critique of Huntington's general proscription against officers being "political," see Brooks 2020, 17-25. The thrust of Brooks's analysis, however, does not tend toward favoring more substantial and open military political activity. She points rather to how Huntingtonian professionalism is insufficient for the preservation of meaningful civilian control when the military's own socialization processes have weakened, when its internal barriers to political activity have waned, and when the pressures on military service-members to engage in partisan political expression have mounted.

14 Many other analysts do not believe that the problem of excessive military influence can be easily set aside, even in "mature democracies"; see especially Feaver 2003.

15 See also the symposia in Strategic Studies Quarterly [2015] 9(3): 1-103, and Armed Forces \& Society [2017] 43(1): 3-52.

16 Gallup. 2019. "Confidence in Institutions." Gallup. Retrieved September 24, 2019 (https://news.gallup. com/poll/1597/Confidence-Institutions.aspx).

17 See also, though more focused on elite opinion, Holsti 2001, 80-84; Gronke and Feaver 2001, 157-160. On the views of U.S. military officers, see also Dempsey 2009; Urben 2013, 2014.

18 Schake and Mattis 2016b, online appendix, 52-54 (https://www.hoover.org/sites/default/files/pages/ docs/civ-mil_1_tabs.pdf).

19 Interestingly, other analysts, examining those same findings, thought the Schake and Mattis results revealed "a troubling level of deference to the military"; see Golby, Cohn, and Feaver 2016, 134.

20 For the Lucid platform, see https://luc.id/lucid-foracademics/. Lucid "collects basic demographic information from all subjects who flow through their doors, facilitating quota sampling to match the U.S. Census demographic margins." While not a probability sample, analyses of Lucid's data confirm that it performs well relative to national benchmarks and that Lucid respondents are naive survey-takers relative to other online respondents. See Coppock and McClellan 2019.

21 On these characteristics, the sample in this Lucid survey is largely comparable to existing national benchmarks, but leans slightly more Democratic and white, substantially less Latino, and somewhat less educated and wealthy. Refer to online appendix 1 , section 1 , table 14 .

22 The survey did not probe respondents' views of Congress's role. For sake of simplicity, it presumed that the "civil" in "civil-military relations" is the executive branch and especially the president. However, civil-military relations operate distinctively in separation-of-powers systems; see Avant 1994, 1996.

23 For detail on the resulting "civilian deference index," refer to online appendix 1, section 4.3.

24 On the Deference Index, refer to online appendix 1 , section 4.1 .

25 On the Oversight Index, refer to online appendix 1 , section 4.2.

26 For the survey, refer to online appendix 3.

27 Appendix 1, section 2.2, figures 5-9.

28 Appendix 1, section 2.2, figures 10-13.

29 A social desirability effect may be exaggerating expressed public trust in the military, but we are skeptical that there are strong incentives for respondents to defer to the military or welcome officers' public involvement in policy debate. Empowering the president or opposing senior officers' overt intrusion into policy debate are less controversial —and not necessarily socially undesirable-stances. Moreover, efforts to estimate the social desirability effect on even military trust show it to be fairly modest, amounting to between 4 and 14 percentage points depending on the question. See Golby and Feaver 2019.

30 Appendix 1, section 2.3, figures 14-17.

31 Appendix 1, section 2.4.

32 Appendix 1, section 2.5.

33 We suspect the oversight data follow principle/ideology rather than political interest because the oversight questions do not emphasize conflicts between the military and the president.

34 Appendix 1, section 2.7. The differences between Trump disapprovers and approvers are statistically significant. Officer approval of mission: $t=-6.75$; $\mathrm{p}<0.000$. Officer disapproval of mission: $t=-8.38$; $\mathrm{p}<0.000$.

35 The difference between Democrats/leaning independents and Republicans/leaning independents is statistically significant $(t=9.94 ; \mathrm{p}<0.000)$. The difference between Trump disapprovers and Trump approvers is statistically significant $(t=10.59$; $\mathrm{p}<0.000$ ).

36 For the Triangle Institute study, refer to online appendix 2, tables 1-12. For the 2013 Hoover Institution study, see Schake and Mattis 2016b, online appendix, 103-104 (https://www.hoover.org/ sites/default/files/pages/docs/civ-mil_2_tabs.pdf).

37 Appendix 1, section 2.6. 
38 Appendix 1, section 3, table $1 \mathrm{~B}$.

39 Appendix 1, section 3, table 1B, Models 1, 2, and 6 .

40 Appendix 1, section 3, table 1B, Models 7-8.

41 For logistic models of the individual deference questions, with results largely paralleling this analysis of the Deference Index, refer to online appendix 1 , section 3 , tables 2-6.

42 Appendix 1, section 3, tables 7-8.

43 Appendix 1, section 3, tables 4-5.

44 Appendix 1, section 3, table 9.

45 Thanks to an anonymous reviewer for suggesting this possibility.

46 As a result, military experience is misleadingly associated with lower scores (less deference) on the Deference Index. Refer to online appendix 1, section 3, tables 1B-6. We thank an anonymous reviewer for pressing us on this point.

47 Refer to online appendix 1, section 3, table 1 .

48 Refer to online appendix 1, section 3, tables 1-6.

49 Appendix 2, tables 13-18.

50 Pew Research Center. 2018. The Public, the Political System, and American Democracy, April, especially pages 29-30 (https://www.people-press. org/2018/04/26/the-public-the-political-system-andamerican-democracy/); Drutman, Lee, Larry Diamond, and Joe Goldman. 2018. "Follow the Leader: Exploring American Support for Democracy and Authoritarianism." Voter Study Group, March (https://www.voterstudygroup.org/publication/ follow-the-leader).

51 See, similarly, Cohen, Raphael S. 2018. "Looking Beyond the Generals in the Room: The Real Cause of America's Civil-Military Malaise." War on the Rocks, March 29.

52 We thank an anonymous reviewer for pressing us on this point. On the limits of military socialization, see Krebs 2004.

53 Appendix 1, section 2.3.

54 See, in outlets across the political spectrum, among many others, Horton, Alex. 2013. "Help Veterans by Taking Them Off the Pedestal.” Atlantic, November 10; Richtel, Matt. 2015. "Please Don't Thank Me for My Service." New York Times, February 21; Coerr, Stanton S. 2015. "3 Reasons to Stop Thanking Me for My Military Service.” The Federalist, July 16; Sjursen, Danny. 2017. "The Hazards of Military Worship." Huffington Post, May 11; French, David. 2017. "Military-Worship Is Bad for the Military." National Review, November 7.

\section{Supplementary Materials}

Appendix 1. 2019 Lucid Data and Analyses

Appendix 2. TISS and ANES Supplementary Analyses
Appendix 3. Survey Instrument

To view supplementary material for this article, please visit http://dx.doi.org/10.1017/S1537592721000013.

\section{References}

Avant, Deborah D. 1994. Political Institutions and Military Change: Lessons from Peripheral Wars. Ithaca,

NY: Cornell University Press. 1996. "Are the Reluctant Warriors Out of Control? Why the U.S. Military Is Averse to Responding to PostCold War Low-Level Threats." Security Studies 6(2): 51-90. - 2005. The Market for Force: The Consequences of

Privatizing Security. Cambridge: Cambridge University Press.

Bacevich, Andrew J. 2005. The New American Militarism: How Americans Are Seduced by War. New York: Oxford University Press.

Betts, Richard K. 1977. Soldiers, Statesmen, and Cold War Crises. Cambridge, MA: Harvard University Press.

Brooks, Risa A. 2020. "Paradoxes of Professionalism: Rethinking Civil-Military Relations in the United States." International Security 44(4): 7-44.

- 2008. Shaping Strategy: The Civil-Military Politics of Strategic Assessment. Princeton, NJ: Princeton University Press.

_ 2009. "Militaries and Political Activity in Democracies." In American Civil-Military Relations: The Soldier and the State in a New Era, ed. Suzanne C. Nielsen and Don M. Snider, 213-239. Baltimore: Johns Hopkins University Press.

- 2013. "The Perils of Politics: Why Staying Apolitical Is Good for Both the US Military \& the Country." Orbis 57(3): 369-79.

. 2019. "Integrating the Civil-Military Relations Subfield.” Annual Review of Political Science 22: 379-98.

Brooks, Risa, Michael Robinson, and Heidi Urben. 2020.

"Huntington, Janowitz, or None of the Above? Conceptions of Professional Norms by Future Army Officers." Presented at the Annual Meeting of the American Political Science Association (online), September 9-13.

Burbach, David T. 2017. "Gaining Trust While Losing Wars: Confidence in the U.S. Military after Iraq and Afghanistan." Orbis 61(2): 154-71.

- 2019. Partisan Dimensions of Confidence in the

U.S. Military, 1973-2016. Armed Forces \& Society 45

(2): 211-33.

Burk, James. 2002. "Theories of Democratic CivilMilitary Relations." Armed Forces \& Society 29(1): 7-29.

Clotfelter, James. 1973. The Military in American Politics. New York: Harper \& Row.

Cohen, Eliot A. 2001. "The Unequal Dialogue: The Theory and Reality of Civil-Military Relations and the 
Use of Force." In Soldiers and Civilians: The CivilMilitary Gap and American National Security, ed. Peter D. Feaver and Richard H. Kohn, 429-458. Cambridge, MA: MIT Press.

- 2002. Supreme Command: Soldiers, Statesmen, and Leadership in Wartime. New York: Free Press.

Cohn, Lindsay, Damon Coletta, and Peter Feaver. 2018. "Civil-Military Relations." In The Oxford Handbook of International Security, ed. Alexandra Gheciu and William C. Wohlforth, 711-726. Oxford: Oxford University Press.

Coletta, Damon, and Thomas Crosbie. 2019. "The Virtues of Military Politics." Armed Forces \& Society 47 (1): 3-24.

Coppock, Alexander, and Oliver A. McClellan. 2019. "Validating the Demographic, Political, Psychological, and Experimental Results Obtained from a New Source of Online Survey Respondents." Research and Politics 6 (1): $1-14$.

Davis, James A. 2001. "Attitudes and Opinions Among Senior Military Officers and a U.S. Cross-Section, 1998-99." In Soldiers and Civilians: The Civil-Military Gap and American National Security, ed. Peter D. Feaver and Richard H. Kohn, 101-128. Cambridge, MA: MIT Press.

de Figueiredo, Jr., Rui J.P., and Zachary Elkins. 2003. "Are Patriots Bigots? An Inquiry into the Vices of In-Group Pride." American Journal of Political Science 47(1): 171-88.

Dempsey, Jason K. 2009. Our Army: Soldiers, Politics, and American Civil-Military Relations. Princeton, NJ: Princeton University Press.

Desch, Michael C. 2001. Civilian Control of the Military: The Changing Security Environment. Baltimore: Johns Hopkins University Press.

—. 2007. "Bush and the Generals." Foreign Affairs 86 (3): 97-108.

Enloe, Cynthia. 2000. Maneuvers: The International Politics of Militarizing Women's Lives. Berkeley: University of California Press.

Feaver, Peter D. 1999. "Civil-Military Relations." Annual Review of Political Science 2: 211-41.

- 2003. Armed Servants: Agency, Oversight, and CivilMilitary Relations. Cambridge, MA: Harvard University Press.

_ 2011. "The Right to Be Right: Civil-Military Relations and the Iraq Surge Decision." International Security 35(4): 87-125.

Finer, Samuel E. 1962. The Man on Horseback: The Role of the Military in Politics. New York: Praeger.

Golby, James, Peter Feaver, and Kyle Dropp. 2018. "Elite Military Cues and Public Opinion About the Use of Military Force." Armed Forces \& Society 44(1): 44-71.

Golby, James Thomas. 2011. "Duty, Honor . . . Party? Ideology, Institutions, and the Use of Military Force."
PhD dissertation, Department of Political Science, Stanford University.

Golby, Jim. 2015. "Beyond the Resignation Debate: A New Framework for Civil-Military Dialogue.” Strategic Studies Quarterly 9(3): 18-46.

Golby, Jim, Lindsay P. Cohn, and Peter D. Feaver. 2016. "Thanks for your Service: Civilian and Veteran Attitudes after Fifteen Years of War." In Warriors \& Citizens: American Views of Our Military, ed. Kori Schake and Jim Mattis, 97-142. Stanford, CA: Hoover Institution Press.

Golby, Jim, and Peter D. Feaver. 2019. "The Determinants of Public Confidence in the Military." Presented at the Annual Meeting of the American Political Science Association. Washington, DC, August 29-September 1.

Gronke, Paul, and Peter D. Feaver. 2001. "Uncertain Confidence: Civilian and Military Attitudes about Civil-Military Relations." In Soldiers and Civilians: The Civil-Military Gap and American National Security, ed. Peter D. Feaver and Richard H. Kohn, 129-163. Cambridge, MA: MIT Press.

Hand, Learned. 1977. The Spirit of Liberty: Papers and Addresses of Learned Hand. 3rd ed. Chicago: University of Chicago Press.

Hendrickson, David. 1988. Reforming Defense: The State of American Civil-Military Relations. Baltimore: Johns Hopkins University Press.

Hill, Andrew A., Leonard Wong, and Stephen J. Gerras. 2013. "Self-Interest Well Understood: The Origins \& Lessons of Public Confidence in the Military." Daedalus 142(2): 49-65.

Holsti, Ole R. 2001. "Of Chasms and Convergences: Attitudes and Beliefs of Civilians and Military Elites at the Start of a New Millennium." In Soldiers and Civilians: The Civil-Military Gap and American National Security, ed. Peter D. Feaver and Richard H. Kohn, 15-100. Cambridge, MA: MIT Press.

Horwitz, Paul. 2007. "Three Faces of Deference." Notre Dame Law Review 83: 1061-146.

Huntington, Samuel P. 1957. The Soldier and the State: The Theory and Politics of Civil-Military Relations. Cambridge, MA: Harvard University Press.

Janowitz, Morris. 1960. The Professional Soldier: A Social and Political Portrait. Glencoe: Free Press.

- 1983. The Reconstruction of Patriotism: Education for Civic Consciousness. Chicago: University of Chicago Press. Jost, Tyler, and Joshua D. Kertzer. 2019. "Armies and Influence: Public Deference to Foreign Policy Elites." Unpublished manuscript, Brown University and Harvard University.

Kemp, Kenneth W., and Charles Hudlin. 1992. "Civil Supremacy over the Military: Its Nature and Limits." Armed Forces \& Society 19(1): 7-26. 
King, David C., and Zachary Karabell. 2003. The Generation of Trust: How the U.S. Military Has Regained the Public's Confidence Since Vietnam. Washington, DC: AEI Press.

Kohn, Richard H. 2002. "The Erosion of Civilian Control of the Military in the United States Today." Naval War College Review 55(3): 8-59.

Krebs, Ronald R. 2004. "A School for the Nation? How Military Service Does Not Build Nations, and How It Might." International Security 28(4): 85-124.

- 2009. "The Citizen-Soldier Tradition in the United States: Has Its Demise Been Greatly Exaggerated?" Armed Forces \& Society 36(1): 153-74.

Krebs, Ronald R., and Robert Ralston. 2020. "Patriotism or Paychecks: Who Believes What about Why Soldiers Serve." Armed Forces \& Society OnlineFirst, April 16.

Lutz, Catherine A. 2001. Homefront: A Military City and the American Twentieth Century. New York: Beacon Press.

Mann, Michael. 1987. "The Roots and Contradictions of Modern Militarism." New Left Review 162: 35-51.

Millar, Katharine M. 2019a. "Support the Troops! Gender and the Transformation of Civil-Military Relations." Unpublished manuscript, London School of Economics and Political Science, London.

— . 2019b. "What Do We Do Now? Examining Civilian Masculinity/ies in Contemporary Liberal Civil-Military Relations." Review of International Studies 45(2): 239-59.

Nielsen, Suzanne C., and Don M. Snider, eds. 2009. American Civil-Military Relations: The Soldier and the State in a New Era. Baltimore: Johns Hopkins University Press.

Owens, Mackubin Thomas. 2015. "Military Officers: Political without Partisanship." Strategic Studies Quarterly 9(3): 88-101.

Recchia, Stefano. 2015. Reassuring the Reluctant Warriors: U.S. Civil-Military Relations and Multilateral Intervention. Ithaca, NY: Cornell University Press.

Richards, Howard. 1964. "Deference." Ethics \& International Affairs 74(2): 135-42.

Robinson, Michael A. 2018. "Danger Close: Military Politicization and Elite Credibility." PhD dissertation, Department of Political Science, Stanford University.

Sagan, Scott D. 2017. "The Korean Missile Crisis: Why Deterrence Is Still the Best Option.” Foreign Affairs 96(6): 72-82.
Sagan, Scott D., and Benjamin A. Valentino. 2017. "Revisiting Hiroshima in Iran: What Americans Really Think about Using Nuclear Weapons and Killing Noncombatants.” International Security 42(1): 41-79.

- 2018. "Not Just a War Theory: American Public Opinion on Ethics in Combat." International Studies Quarterly 62(3): 548-61.

Schake, Kori, and Jim Mattis. 2016a. "Ensuring a CivilMilitary Connection.” In Warriors \& Citizens:

American Views of Our Military, ed. Kori Schake and Jim Mattis, 287-326. Stanford, CA: Hoover Institution Press.

— of Our Military. Stanford, CA: Hoover Institution Press.

Schatz, Robert T., Ervin Staub, and Howard Lavine. 1999. "On the Varieties of National Attachment: Blind versus Constructive Patriotism.” Political Psychology 20 (1): 151-74.

Schauer, Frederick. 2008. "Authority and Authorities." Virginia Law Review 94(8): 1931-61.

Schiff, Rebecca L. 1995. "Civil-Military Relations Reconsidered: A Theory of Concordance." Armed Forces \& Society 22(1): 7-24.

- 2009. The Military and Domestic Politics: A Concordance Theory of Civil-Military Relations. London: Routledge.

Snider, Don M. 2008. "Dissent and Strategic Leadership of the Military Professions." Orbis 52(2): 256-77.

Soper, Philip. 2002. The Ethics of Deference: Learning From Law's Morals. Cambridge, MA: Cambridge University Press.

Urben, Heidi. 2013. "Party, Politics, and Deciding What Is Proper: Army Officers' Attitudes after Two Long Wars." Orbis 57(3): 351-68.

— 2014. "Wearing Politics on Their Sleeves? Levels of Political Activism of Active Duty Army Officers." Armed Forces \& Society 40(3): 568-91.

Van Hiel, Alain, and Ivan Mervielde. 2002. "Explaining Conservative Beliefs and Political Preferences: A Comparison of Social Dominance Orientation and Authoritarianism." Journal of Applied Social Psychology 32(5): 965-76.

Welch, Claude, ed. 1987. Civilian Control of the Military. Albany: State University of New York Press. 